Cardiovascular \& Hematological Agents in Medicinal Chemistry

Volume 5, Number 1, January 2007, pp. 67-77(11)

(c) 2007 Bentham Science Publishers
Archimer, archive institutionnelle de l'Ifremer http://www.ifremer.fr/docelec/

\title{
Neoangiogenesis Induced by Progenitor Endothelial Cells: Effect of Fucoidan from Marine Algae
}

\author{
C. Boisson-Vidal ${ }^{\star 1,2}$, F. Zemani ${ }^{1}$, G. Calliguiri ${ }^{3}$, I. Galy-Fauroux ${ }^{1,4}$, S. Colliec-Jouault ${ }^{5}$, D. \\ Helley ${ }^{1,4,6}$ and A-M. Fischer $r^{1,4,6}$
}

1 INSERM U765, Faculté de Pharmacie, 4 avenue de l'Observatoire 75270 Paris Cédex,

France

2 : CNRS, Délégation IDF Est, Thiais, France

3 : INSERM UMRS 681 Paris, France

4 : Université Paris Descartes, Faculté de Médecine, Paris, France

5 : IFREMER Nantes, France

6 AP-HP, Hôpital Européen Georges Pompidou, Service d'Hématologie Biologique, Paris, France

*: Dr Catherine Boisson-Vidal, INSERM U428, Faculté de Pharmacie 4 av. de

l'Observatoire, 75270 Paris cedex 06, France. Tel 33 (0)1 537398 28, Fax 33(0)1 440717

72; e-mail: catherine.boisson-vidal@univ-paris5.fr:

\begin{abstract}
:
Fucoidans -- sulphated polysaccharides extracted from brown algae - could be beneficial in patients with ischemic diseases. Their antithrombotic and proangiogenic properties promote in animals, neovascularization and angiogenesis which prevent necrosis of ischemic tissue. In 1997, endothelial progenitor cells were first identified in human peripheral blood. They are recruited from bone marrow and contribute to neovascularization after ischemic injury. Mobilization of these cells in ischemic sites is an important step in new vessel formation. It is thought that the progenitors interact with endothelial cells, then extravasate and reach ischemic sites, where they proliferate and differentiate into new blood vessels. Although chemokines, cytokines and adhesion molecules are thought to be involved, the precise mechanism of progenitor mobilization is not fully understood. Recent studies suggest that stromal-derived factor 1 plays a critical role at several steps of progenitor mobilization. Given the role of proteoglycans within bone marrow, at the endothelium surface, and in growth factor and chemokine binding, fucoidans might influence the mobilization of endothelial progenitor cells and their incorporation in ischemic tissue. This review provides an update on circulating endothelial progenitors and their role in neovascularization. It focuses on recent advances in our understanding of interactions between these progenitor cells and exogenous sulphated polysaccharides, and their implications for understanding the fucoidan mechanism of action.
\end{abstract}

Keywords: Fucoidan; sulphated polysaccharides; endothelial progenitor cells; neovascularization; angiogenesis; cytokines; growth factors 


\section{INTRODUCTION}

This review examines the effect of fucoidans -- sulphated polysaccharides extracted from brown seaweeds -- on angiogenesis and vasculogenesis.

Angiogenesis is defined as the formation of new blood vessels by sprouting from a pre-existing vascular network [1-3]. It differs from vasculogenesis, a process in which de novo endothelial cell progenitors emerge from the mesoderm, form vessel rudiments, and organize to form mature vessels [4-7]. Until recently, vasculogenesis was considered to be restricted to the embryo, while new blood vessel formation in adults was exclusively attributed to angiogenesis. In 1997 Asahara and co-workers detected endothelial progenitor cells (EPC) in human adult peripheral blood [8]. These cells appear to be recruited from bone marrow and incorporated into sites of active revascularization [5, 6, 9-12]. They contribute to neovascularization after ischemic injury and are involved in re-endothelialization of vessel implants [13-15]. Their local transplantation into ischemic tissue quantitatively improves neovascularization, collateral vessel formation, and blood perfusion $[5,11,16-21]$. Recent experiments show that this transplantation correlates with an increase in capillary densities $[16,17]$. EPCs are present at low frequencies in human adult bone marrow and peripheral blood, and in umbilical cord blood. These immature $\mathrm{CD} 34^{+}$cells can be mobilized from animals bone marrow into the circulation by several compounds including sulphated polysaccharides such as fucoidans [22].

The anticoagulant activity and potentially severe adverse effects of heparin prompted research into other natural or synthetic sulphated polysaccharides. Fucoidans are of particular interest : at the the same antithrombotic activity as heparin, they have a weaker anticoagulant effect and a lower risk of hemorrhage [23]. They significantly accelerate the interaction between serpin (mainly heparin cofactor II or HCII) and coagulation proteases [24]. They also have various biological properties, such as antiinflammatory [25, 26] and antiviral activity [27], and can modulate the angiogenic activity of proangiogenic growth factors [28]. Injection of these polyfucoses reduces intimal hyperplasia [29], promotes revascularization in a rat model of critical hind-limb ischemia [30], and mobilizes bone marrow stem cells in peripheral blood [22]. 
How fucoidans promote angiogenesis is not fully clear. However, several studies have shown that the biological properties of these sulphated polyfucoses are a consequence of their charge density and are determined by detailed structural features [31, 32]. Fucoidans seem to act like glycosaminoglycans (GAGs) present on the cell membrane. Recent studies of GAGs provide insights into the possible fucoidan mechanism of action.

Because of their ionic structure, fucoidans have diverse biological properties, ranging from relatively simple mechanical support functions to more intricate effects on cellular processes [32, 33]. Fucoidans bind proteins such as adhesion proteins [34], growth factors [35], cytokines [36], and a variety of enzymes, including coagulation proteases [37-39]. As a result, they can participate, like GAGs, in cell adhesion, migration, proliferation and differentiation -- the key steps of the angiogenic process. They can also modulate clinically relevant phenomena such as angiogenesis, tumor metastasis, and atherosclerosis. In-depth studies of the biochemical mechanisms underlying interactions between GAGs (especially heparan sulphate proteoglycans, or HSPGs, mainly located in the basement membrane and on the mammalian cell surface) and molecules involved in these processes may help us to understand how fucoidans influence angiogenesis and vasculogenesis.

This review provides an update on the effects of fucoidans on angiogenesis and vasculogenesis, the biochemical bases of their interaction with angiogenic growth factors and cell surface molecules, and their mechanisms of action.

\section{I - CONTRIBUTION OF ADULT BONE MARROW-DERIVED CELLS TO BLOOD VESSEL FORMATION}

Postnatal neovascularization comprises angiogenesis and vasculogenesis and is regulated by complex interactions of various growth factors, circulating bone marrow-derived precursors, and mature endothelial cells $[4-6,40,41]$.

Angiogenesis is a multistep process leading to the formation of new vessels by "sprouting" from preexisting vessels [1-3]. It is initiated by angiogenic growth factors such as VEGF. In contrast, vasculogenesis is related to the emergence of blood vessels de novo from vascular endothelial precursor cells known as angioblasts, which differentiate into endothelial cells [6, 42]. During the 
earliest stages of mammalian development, free angioblasts develop in the mesoderm, assemble into cords and differentiate into an endothelium to form blood vessels [43, 44]. This creates the primary network of vascular endothelial cells that will eventually become major blood vessels. Angiogenesis subsequently remodels this network into small blood vessels by sprouting from the pre-existing vascular network and thereby completing the embryo's circulatory system. These two processes occur simultaneously throughout embryonic development.

Until recently, neovascularization in adults was thought to result exclusively from proliferation, migration, and remodeling of pre-existing endothelial cells, i.e. angiogenesis $[1,43]$. The formation of blood vessels from angioblasts was thought to be restricted to the period of embryogenesis. In 1996, Noishiki et al. raised the possibility that endothelialization of artificial vascular prostheses might be promoted by bone marrow transplantation [15]. Several studies then showed that cells mobilized from bone marrow were incorporated into sites of active neovascularization $[8,45]$ and participated in the endothelialization of implanted artificial vessel grafts $[9,14]$. This prompted researchers to recognize the existence of circulating EPC, and the importance of postnatal vasculogenesis. Autologous infusion of EPC would potentially be a promising therapy for revascularising ischemic tissues.

EPC were isolated from peripheral blood and human umbilical cord blood $[6,8,17]$. These cells and blood cells (erythrocytes, platelets and leukocytes) arise from a common precursor cell, the hemangioblast [46, 47]. Upon appropriate cytokine stimulation, hemangioblasts can give rise to hematopoietic or endothelial cell (EPC) precursors. The two cell types are identified by the presence of common surface antigens such as vascular endothelial cell growth factor receptor (VEGFR-2, also known as Flk-1/KDR), angiopoietin receptor (Tie-2), and CD34 [48-51]. Persistent expression of VEGFR-2 is associated with differentiation along the endothelial lineage, whereas loss of VEGFR-2 expression characterizes differentiating hematopoietic progeny $[7,8,13,17,51]$.

EPC recruitment from bone marrow is very complex [52, 53]. Several studies have shown that regional ischemia is the main factor responsible for local induction of angiogenesis; the extent to which angiogenesis is enhanced is related to the severity of ischemia [40, 45, 54]. High levels of proangiogenic factors such as basic fibroblast growth factor (FGF-2), VEGF [53, 55, 56], angiopoeitin 
[55], stromal-derived factor (SDF-1) [55, 57-60] and interleukin-8 (IL-8) [61-63], released by ischemic tissue, mobilize these cells in the peripheral circulation and enhance their recruitment into the vasculature [3, 52, 53]. Drugs like statins [53, 64], erythropoietin [65], estrogen and fucoidans [22] can also increase the number of mobilized EPC.

After an initial ischemic event, EPC move from the blood into tissues, attracted by proangiogenic factors -- chemoattractants produced by the local inflammatory response which activates the endothelium [9]. These chemoattractants are released from HSPGs by endosulfatases [57, 66, 67]. These latter enzymes break the association between angiogenic growth factor and HSPGs by clipping off key sulphates from heparan sulphate, thereby allowing proangiogenic factors to promote angiogenesis. This step is followed by cell tethering and rolling along the vessel, strong adhesion, and entry into the damaged tissue. A new vascular network develops, then angiogenesis remodels this network into small blood vessels by sprouting.

Throughout this process, the extracellular matrix (ECM) ensures essential functions by supporting key signaling events involved in regulating endothelial cell migration, invasion, proliferation and survival [68]. This process is characterized by changes in endothelial cell-ECM interactions. Activation of endothelial cells or EPC induced by proangiogenic factors is followed by disruption of the basement membrane and subsequent cell migration towards the ischemic stimulus. During degradation of their subendothelial basement membrane, activated cells secrete proteases such as elastase, cathepsin G, urokinase-plasminogen activator (uPA) and matrix metalloproteinases (MMPs) [69]. All these events are critical for the initiation of angiogenesis. Migration of endothelial cells is impossible without the key matrix degrading proteases MMP-2 and uPA. Through the effect of VEGF, this activation induces strong expression of $\alpha v \beta 3$ and $\alpha v \beta 5$ integrins (characteristic of proliferating and migrating endothelial cells) [70, 71], and expression of $\alpha 1 \beta 1$ and $\alpha 2 \beta 1$ (key interstitial collagen receptors) [68].

Neighboring endothelial cells then migrate and proliferate, leading to the formation of endothelial cell sprouts and capillary tubes, followed by tight junctions and synthesis of a new basement membrane. 


\section{II - EFFECTS OF EXOGENOUS SULPHATED POLYSACCHARIDES ON ANGIOGENESIS PROCESS}

In vitro models used to test candidate drugs able to modulate angiogenesis explored the different steps of angiogenesis, i.e. endothelial cell proliferation, adherence, migration and capillary sprouting.

Several sulphated polysaccharides, like heparin [72-75], sulphated dextrin [76], pentosane polysulphate [77], structural mimics of heparan sulphate $[78,79]$ and carrageenans from red algae [80, 81], have been found to inhibit angiogenesis in vitro. Most of them inhibit new vessel formation through a direct effect on endothelial cells after being added to the experimental medium. They inhibit cultured endothelial cell proliferation, chemotaxis and adhesion to the ECM. They inhibit growth factor binding to cognate receptors, prevent their interaction with cell-surface HSPGs and tyrosinekinase receptors and inhibit cleavage of heparan sulphate by heparanases $[66,72,82]$. These properties are due in part, to the capacity of these polyanions to bind to the heparin-binding site of growth factors or heparanases via their sulphate groups. Some of them are able to inhibit normal angiogenesis in the chick embryo chorioallantoic membrane $[75,83,84]$. They can also inhibit neovascularization $[85,86]$ and suppress tumor angiogenesis in experimental models $[74,76,77,87,88]$. Their effect on angiogenesis appears to be mediated mainly by their negative charge, molecular weight and degree of sulphation, rather than by a specific carbohydrate structure. Hahnenberger et al. showed that the antiangiogenic properties of heparin were related to the presence of a structure made up of the $-[\mathrm{GlcA}$ beta 1,4-GlcNAc alpha 1,4]n-sequence, which is found in non sulphated regions of HSPGs [78].

Interestingly, contrary to other polysaccharides, low-molecular-weight fucoidan fractions potentiate angiogenesis in vitro [28, 89] and in vivo [30]. Fucoidan pretreatment of human umbilical vein endothelial cells (HUVEC) or EPC for 36 to 72 hours enhances FGF-2-dependent angiogenesis [28, 90, 91], while the addition of high-molecular-weight (HMW) fucoidans directly to the culture medium inhibits growth factor-induced vascular tube formation by endothelial cells [89, 92, 93].

\section{III - EFFECTS OF FUCOIDAN ON ANGIOGENESIS AND VASCULOGENESIS}

Fucoidans are mainly composed of sulphated L-fucose. They are easily extracted from the cell wall of various brown algae [32,33], the egg jelly coat of sea urchins [94], and the body wall of sea cucumber 
[95]. After reduction into low-molecular-weight fractions by radical depolymerization (ranging from 4000 to $15000 \mathrm{~g} / \mathrm{mol}$ ), they have been used for in vitro and in vivo coagulation assays. They act as modulators of coagulation [37, 96-101] and also have antithrombotic activity in vivo in rabbit models of venous thrombosis (jugular venous stasis thrombosis induced by factor Xa injection) and arterial thrombosis [35, 102-104]. Compared to heparin, at the same level of antithrombotic activity in rabbits, they have lower anticoagulant activity and a lower hemorrhagic risk [104]. Their anticoagulant activities are mediated both by antithrombin and by heparin cofactor II $[96,97]$. In the same manner, fucoidans can increase the antithrombin activity of protease nexin-1 (PN-1), a pericellular serpin expressed by vascular cells [39]. They can thus significantly reduce circulating levels of thrombin by catalyzing its inhibition. Fucoidans stimulate endothelial release of tissue factor pathway inhibitor, a potent inhibitor of the coagulation cascade [105]. Finally, fucoidans can promote fibrinolysis by potentiating plasminogen activators $[106,107]$ and reducing plasminogen activator inhibitor-1 (PAI-1) release by endothelial cells [108]. All these effects contribute to the antithrombotic action of fucoidans.

Besides their anticoagulant and antithrombotic activities, fucoidans can induce angiogenesis in vitro by modulating the proangiogenic properties of heparin-binding growth factors such as FGF-2. We have previously shown that pre-treatment of HUVEC with low-molecular-weight fucoidan fractions (LMW fucoidan $4000 \mathrm{~g} / \mathrm{mol}$, and fucoidan $15000 \mathrm{~g} / \mathrm{mol}$ ) extracted from the brown algae Ascophyllum nodosum, enhances FGF-2-induced vascular tube formation in a standard in vitro Matrigel model [28, 90]. LMW fucoidan combined with FGF-2 improves endothelial cell proliferation in vitro [109] and cell adhesion to laminin [91]. In the presence of FGF-2, the same fraction induces human EPC to adopt a proangiogenic phenotype [91] Fig. (1). It also enhances EPC proliferation Fig. (1.1) and motility Fig.(1.3). Fucoidan-treated EPC show enhanced migration in the Boyden chamber assay, including increased chemotaxis towards VEGF Fig. (1.3). Fucoidan pretreatment further enhances the formation of FGF-2-induced vascular-cord-like structures in Matrigel Fig. (1.4). The tubular network is significantly more extensive than that obtained with control cells. This pretreatment provokes marked EPC shape changes, with actin cytoskeleton reorganization and the emergence of protrusions 
that closely mimic precapillary cords observed during angiogenesis [91]. Over the course of $18 \mathrm{~h}$, these cells form hollow tubes on Matrigel.

More recent investigations have established the feasibility of using fucoidan to augment collateral artery development in animal models of hindlimb ischemia. Intravenous administration of a commercial HMW fucoidan extracted from Fucus vesiculosus prolonged the time required for complete occlusion of arterioles and venules by a factor of almost seven [35]. Recently, Luyt et al. administered the LMW fucoidan fraction and/or FGF-2 to rats with acute hindlimb ischemia at daily intramuscular doses of $5 \mathrm{mg} / \mathrm{kg} / \mathrm{day}$ and $1 \mu \mathrm{g} / \mathrm{kg} /$ day, respectively [30]. After 14 days of treatment, compared to controls, angiography and necropsy measurement of capillary density showed evidence of increased collateral vessel formation in the lower limb. LMW fucoidan injection improved residual muscle blood flow compared with the control group [30]. This LMW fucoidan is also able to inhibit smooth muscle cell proliferation in vitro [29, 110-112] and in vivo [29]. Its injection reduced neointimal hyperplasia in a rat carotid balloon injury model [110] and after stenting in rabbit iliac arteries angioplasty model [29].

Recently, we have observed that intraperitoneal (IP) injection of LMW fucoidan induces rapid mobilization of immature $\mathrm{CD} 34^{+} / \mathrm{CD} 31^{+} / \mathrm{CD} 45^{-}$murine progenitors from bone marrow, about as potently as IP injection of VEGF (0.5 $\mu \mathrm{g} / \mathrm{kg} / \mathrm{day})$ Fig. (2) [113]. Other researchers have shown rapid mobilization of hematopoietic progenitors after IP injection of HMW fucoidan to rats $[114,115]$. This mobilization correlates with the release of GAG-bound SDF-1 from its tissue storage sites into the circulation on fucoidan administration [22]. Injection of LMW fucoidan significantly increases the SDF-1 level in rat and mouse peripheral blood but does not modify MMP-9 levels [30, 113]. The injection of heparin and LMW heparin in the same experimental conditions does not induce angiogenesis $[30,73]$.

\section{IV - MECHANISM OF ACTION OF FUCOIDAN}

What is the mechanism of action of fucoidan ? How does fucoidan differ from other sulphated polysaccharides like heparin? How to explain these properties of fucoidan, when heparin pretreatment 
of EPC does not potentiate these cells' proangiogenic properties in vitro and has no effect on revascularization of ischemic tissue in vivo?

The biological properties of fucoidan, a sulphated polyfucose, depend on the molecular structure. A wide range of natural and synthetic anionic compounds have been found to interact with proangiogenic growth factors, and especially FGFs [116-119]. Their interaction with acidic FGF (FGF-1) appears to be primarily related to their charge density $[117,119,120]$. It also depends on the size and location of sulphate groups, the degree of sulphation, and the saccharide chain composition. The minimal sequence of sulphated polysaccharides necessary to heat-stabilize FGF-1 is four monosaccharide units [119]. The structural requirements for fucoidan interaction with coagulation factors and target proteases are also stereospecific [31, 32].

The type of fucoidan, its sulphation and molecular weight, and the conformation of its sugar residues varies with the seaweed species $[32,100,121]$. According to recent studies, fucoidans from Ascophyllum nodosum and Fucus vesiculosus, referred to in this paper as LMW fucoidan and HMW fucoidan, respectively, are based on L-fucose with a repeating structure of alternating $\alpha(1 \rightarrow 3)$ and $\alpha(1 \rightarrow 4)$ glycosidic bonds [100, 122, 123] and sulphate groups at position 2 or 4 Fig.(3A) $[122,124]$. For its part, heparin is composed of alternating D-glucosamine and uronic acid (L-iduronic or Dglucuronic acid) residues, that have heterogeneous sizes and degrees of sulphation Fig. (3B) [125].

Various data indicate that sulphation is critical for fucoidan activity in vivo. In particular, desulphated fucoidan fails to promote angiogenesis in vitro [91] or to induce immature $\mathrm{CD}^{3} 4^{+}$cell mobilization in vivo [115]. Native fucoidan-induced mobilization is abolished in the presence of protamine [114]. The predominant sulphation pattern consists of a trisulphated disaccharide repeat similar to that found in heparin $[122,125]$. Yet heparin has no effect on angiogenesis induced by HUVEC in vitro [28], and does not induce significant immature $\mathrm{CD} 4^{+}$cell mobilization [115]. Furthermore, heparan sulphate Fig. (3B), pentosan sulphate Fig. (3C) and chondroitin sulphate Fig. (3D-E), which exhibit anticoagulant activities, inhibit angiogenesis in vitro and are unable to induce significant stem cell mobilization in the blood circulation [114]. Thus, sulphate groups alone are unlikely to be responsible for the effects of fucoidan. 
The fucosyl backbone may have an important role in fucoidan properties. Fucosylated chondroitin sulphate species, made up of alternating $\beta$-D-glucuronic acid and $\mathrm{N}$-acetyl- $\beta$ - D-galactosamine units with branches of sulphated fucose Fig. (3F), potentiate FGF-2-induced tubular morphogenesis in vitro [126] and also trigger an increase in blood SDF-1 levels and immature cell mobilization [22]. Like fucoidan, these chondroitin sulphate species that bear sulphated fucose chains express antithrombotic activity in experimental animals with venous and arterial thrombosis [127]. Branched sulphated fucoses are the key motif responsible for this activity, as shown by comparing native and chemically modified defucosylated and/or desulphated chondroitins [126]. The number of sulphate groups, and changes to the molecular backbone, significantly influence the biological properties of these compounds.

Fucoidan can disrupt heparan sulphate-growth factor/cytokine complexes, and can substitute for cellsurface heparan sulphates in stabilizing the growth factor/growth factor receptor interaction.

\section{Fucoidan binds growth factors and is capable of modulating the biological activity of} angiogenic heparin-binding growth factors

Owing to its ionic structure, fucoidan, like heparin, can bind and modulate the activity of a large number of proteins $[33,128]$ including proteases $[32,38,101]$, cytokines $[36,67]$ and GFs $[35,129$, 130]. It can thereby interfere with cell-cell and cell-matrix adhesion [34] and promote the release of growth factor molecules bound to the cell surface. Like GAGs, it can protect these factors against proteolytic degradation $[117,131]$ and act as tissue organizers [132]. As a result, fucoidan affects many biological activities in vitro, such as coagulation [96, 97, 100], inflammation [26, 133], viral infection [27], fertilization [33, 134] and angiogenesis [28, 90, 91]. Fucoidan might act as GAGs present on the cell surface or in extracellular matrices. It can thus interact directly with growth factors and cell membranes.

Fucoidan is capable of modulating the biological activity of angiogenic heparin-binding GFs and cytokines through different mechanisms. It can interact with growth factors through its soluble, ECMassociated or cell-surface forms, thereby controlling growth factor bioavailability. Fucoidan can also 
displace endogenous growth factors from their tissue heparan sulphate storage sites. It can stabilize growth factor binding to specific cell surface receptor proteins, inducing a conformational change that facilitates GF-GF receptor interaction. As a result, it may increase the radius of growth factor diffusion.

\section{Fucoidan interacts with cell membranes}

The proangiogenic activity of fucoidan is also related to direct interaction of the polysaccharide with cell membranes Fig. (4). Experiments underway in our laboratory indicate that FITC-fucoidan binds to the EPC outer membrane and is internalized by endocytosis within 30 minutes. Because fucoidan binds to cell membranes, it could increase local growth factor concentrations in the close vicinity of the relevant receptor. Endothelial cell surface-bound fucoidan could also act as a co-receptor for angiogenic growth factors.

Fucoidan may mediate growth factor-induced EPC differentiation by interacting with a "receptor" that promotes endothelial cell adhesion, migration, proliferation and differentiation, and that co-operates with a growth factor receptor, transducing the intracellular signals required to induce the angiogenic phenotype. This putative fucoidan receptor might contain a carbohydrate-binding domain that interacts with the fucoidan carbohydrate backbone. Candidates include E-selectin and CD44 -- cell adhesion molecules that are present on the endothelial cell membrane and are expressed by EPC. Specific carbohydrate modifications such as fucosylation and sulphation are critical for selectin binding [135]. Because of the spatial pattern of the sulphated saccharide structure, fucoidan can mimic the clustering of sulphated, sialylated and fucosylated oligosaccharides on the cell surface and can provide the appropriate structural backbone to bind selectins. This is in keeping with previous studies showing the high affinity of selectins for HMW fucoidan $[136,137]$. Nevertheless, according to Frenette et al, HMW fucoidan also acts in a selectin-independent fashion, as it is effective in selectin-deficient mice [115]. HMW fucoidan can bind to non hematopoietic cells lacking selectins [138]. 
A recent study showed that this HMW fucoidan was also able to bind to non selectin receptors such as integrin $\alpha_{M} \beta 2$ on myeloid cells [139]. Integrins can transduce extracellular signals [140]. The possible collaboration of $\alpha_{M} \beta 2$ or other integrins with fucoidan remains to be addressed.

We have shown that tube formation correlates with overexpression of the $\alpha 6$ integrin subunit on the endothelial cell surface [28, 90, 91]. RT-PCR revealed that larger amounts of $\alpha 6$ mRNA were produced after LMW fucoidan stimulation. This $\alpha 6$ overexpression results from transcriptional upregulation [90]. The fucoidan-mediated increase in $\alpha 6$ integrin subunit expression is associated with increased cell adhesion to laminin [91]. The impact of fucoidan on $\alpha 6$ subunit expression is less marked in EPC and is related to baseline $\alpha 6$ subunit integrin expression (stronger on EPC than on HUVEC) [91]. The integrin $\alpha 6$ chain, when assembled with integrin $\beta 1$ or $\beta 4$ subunits, forms major receptors for laminin. In human bone marrow, laminin isoforms are present at sites of hematopoietic cell trafficking [141] and promote progenitor adhesion and migration through interaction with integrin $\alpha 6 \beta 1$ [142]. According to Qian et al., $\alpha 6$ integrins function in vivo as hematopoietic stem cell and progenitor cell homing receptors [143]. The effect of fucoidan on $\alpha 6$ expression on the cell membrane must have a major impact on the migration and mobilization of stem cells in vivo. The observed $\alpha 6$ overexpression on the endothelial cell surface is partly mediated by FGF-2 and HSPGs [90]. Stripping heparan sulphate from HUVEC with heparitinases I, II and III results in a loss of FGF-2-induced $\alpha 6$ overexpression. However, although greatly reduced, $\alpha 6$ expression remains significantly higher in LMW fucoidan-pretreated cells, suggesting a direct effect of the fucoidan. Even in the absence of exogenous FGF-2, LMW fucoidan triggers limited $\alpha 6$ overexpression. Another pathway for the polyfucose, differing from that involving HSPG and/or FGF receptors, seems to coexist in endothelial cells. HSPGs can transduce extracellular signals analogous to signal transduction by growth factor receptors [144]. Fucoidan may act as direct signal transducers Fig. (4C). We cannot rule out the possibility that cell membrane-bound fucoidan may participate directly in signal transduction in response to growth factor binding by interacting directly with FGF-2 receptors. The idea of co- 
receptors acting as signaling molecules independently of their role as receptor binding partners is just beginning to be appreciated $[145,146]$.

Throughout our experiments, we never detected variations in the expression of the laminin receptor $\beta 1$ subunit. This is consistent with the study of Sastry et al suggesting that the $\alpha 6$ subunit regulates differentiation, whereas the $\beta 1$ subunit triggers proliferation : a $\alpha 6 / \beta 1$ ratio below one triggers proliferation, while a ratio above one triggers differentiation [147]. At the concentrations inducing $\alpha 6$ overexpression, fucoidan has no effect on the expression of other endothelial markers (KDR, Flt-1, Tie-2, PECAM, CD144).

\section{Fucoidan enhances EPC mobilization through SDF-1 release}

In vivo, fucoidan is exposed to a complex environment containing numerous proteins in solution and bound to cell surfaces. It can thus bind to and inactivate cationic proteins, and act on other proteins, possibly triggering a cellular response on top of its anticoagulant activity. Part of the fucoidan can interact with proteases involved in coagulation (e.g. thrombin) and with protease inhibitors such as antithrombin and HCII $[24,37,38]$. It can thus reduce circulating levels of thrombin by catalyzing its inhibition. On the other hand, fucoidan can bind to adherent proteins such as fibronectin, collagen and laminin, which are all expressed in bone marrow [34]. Perfusion with HMW fucoidan was shown to reduce neutrophil [148] and eosinophil [149] migration to sites of inflammation, as well as neutrophil infiltration and myocardial injury after ischemia/reperfusion $[150,151]$. Intravenous infusion of HMW fucoidan has protective effects in rat models of myocardial ischemia [150]. Fucoidan might compete with EPC for binding to ECM proteins or proteoglycans that could contribute to EPC release. Finally, fucoidan can bind with high affinity to EPC and enhance their motility.

How does fucoidan influence EPC mobilization? More and more studies are highlighting the crucial role of GAGs in mediating EPC recruitment and homing to ischemic tissues [152-154]. Our findings and those of Sweeney et al throw light on the mechanisms of action of fucoidan on angiogenesis induced by EPC [114] Fig. (5). 
1 - Several lines of evidence suggest that fucoidan acts through SDF-1. Injection of LMW fucoidan to rats and mice significantly increases the SDF-1 level in peripheral blood [30]. High levels of SDF-1 mobilize EPC in the peripheral circulation and enhance their recruitment to the vasculature $[55,57-$ 59]. The cytokine is anchored to the membrane of stromal cells, endothelial cells or the ECM by binding to HSPG [152]. Fucoidan could thus specifically displace sequestered SDF-1 from its HSPG anchors and thus contribute to its release into the circulation. According to Sweeney et al. [22, 114], who are working on hemoatopoietic progenitors, the amount of SDF-1 released into the circulation is sufficient to trigger the observed cell mobilization. In addition to SDF-1, levels of other chemokines (IL-6, IL-8) or cytokines (granulocyte CSF, macrophage CSF) are also increased after fucoidan treatment, possibly owing to their release from HSPGs [114]. In addition to the contribution of EPC to newly formed vessels, enhanced SDF-1 expression, which can activate EPC, may thus contribute to improving revascularization of ischemic tissue, as observed by Luyt et al. after IM injection of LMW fucoidan [30]. These results also explain the efficacy of the fucoidan on intimal growth after stenting in rabbits [29].

2 - Fucoidan ligation to the endothelium might trigger signaling events that could result in EPC egress into the circulation. However, during transmigration through the endothelium, the progenitors traverse the endothelial cell monolayer and the underlying subendothelial basement membrane. Consequently, transmigrating cells interact with endothelial cells, GAG and EMC adhesion proteins. The laminin receptor integrin $\alpha 6$, involved in the homing of stem cells to bone marrow [143], is expressed by EPC [91]. Its expression might be required for EPC migration, and its overexpression after fucoidan pretreatment might facilitate EPC homing towards ischemic sites.

3 - Finally, adhesion receptors like selectins are important for cell migration and extravasation to ischemic sites. During induction of mobilization, the traffic between bone marrow and blood is bidirectional. According to Frenette et al, blocking endothelial selectins may prevent progenitors from reentering the bone marrow [115]. Fucoidan binding to selectins might thus disrupt EPC interaction with bone marrow stromal cells and thereby increase circulating stem cell/progenitor numbers. 
Fucoidan can also compete with proteoglycans found on the ECM or on stromal/endothelial cells within the bone marrow environment.

In conclusion, endothelial progenitor cells play a crucial role in postnatal neovascularization. Increasing evidence suggests that transplantation of culture-expanded progenitor cells or bone marrow-derived progenitor cells may successfully promote neovascularization of ischemic hindlimbs $[12,16]$. Further evidence indicates that not only the cell number but also functional properties of transplanted cells determine the outcome of autologous stem cell transplantation [155]. Fucoidan prevents arterial thrombus growth in animals, with a lower hemorrhagic risk than heparin. It also inhibits smooth muscle cell proliferation, triggers mobilization of endothelial progenitor cells after IP injection, and induces immature $\mathrm{CD} 34^{+}$cells to adopt a proangiogenic phenotype. Fucoidan could thus become an interesting drug for promoting revascularization of ischemic tissues.

Acknowledgments: This paper draws on 15 years of collective work at Laboratoire de Recherches sur les Macromolécules (UMR CNRS FRE 2314 (1987-2003), URM2 CNRS/IFREMER (1990-1998)) and Laboratoire d'Hematologie (Prof. A-M Fischer, INSERM U428, Université Paris Descartes). This research was supported by funds from Centre National de la Recherche Scientifique (CNRS), French Marine Research Institute (IFREMER), Institut National de la Santé et de la Recherche Médicale (INSERM), Laboratoires Fournier, Groupe d'Etude et de Recherches sur l'Hémostase (GEHT), French Hematology Society (SFH); Réseau «Cellules Souches INSERM»University Paris Descartes, University Paris 13 and Ministère de la Recherche et de l'Enseignement Supérieur. 


\section{Reference List}

1, Folkman, J.: Nat. Med. 1995, 1, 27.

2, Risau, W.: Nature 1997, 386, 671.

3, Carmeliet, P.: Nat. Med. 2003, 9, 653.

4, Rafii, S.: J. Clin. Invest. 2000, 105, 17.

5, Asahara, T.; Isner, J.M.: J. Hematother. Stem Cell Res. 2002, 11 , 171.

6, Jain, A.K.: Nature Med. 2003, 9, 685.

7, Urbich, C.; Dimmeler, S.: Circ. Res. 2004, 95 , 343.

8, Asahara, T.; Murohara, T.; Sullivan, A.; Silver, M.; van der Zee, R.; Li, T.; Witzenbichler, G.; Schatteman, G.; Isner, J.M.: Science 1997, 275 , 964.

9, Shi, Q.; Rafii, S.; Wu, M.H.; Wijelath, E.S.; Yu, C.; Ishida, A.; Fujita, Y.; Kothari, S.; Mohle, R.; Sauvage, L.R.; Moore, M.A.S.; Storb, R.F.; Hammond, W.P.: Blood 1998, 92 , 362.

10, Rafii, S.; Meeus, S.; Dias, S.; Hattori, K.; Heissig, B.; Shmelkov, S.; Rafii, D.; Lyden, D.: Semin. Cell Dev. Biol. 2002, $13,61$.

11, Badorff, C.; Dimmeler, S.: Handb Exp Pharmacol 2006, 174 , 283.

12, Shintani, S.; Murohara, T.; Ikeda, H.; Ueno, T.; Sasaki, K.; Duan, J.; Imaizumi, T.: Circulation 2001, $103,897$.

13, Peichev, M.; Naiyer, A.J.; Pereira, D.; Zhu, Z.; Lane, W.J.; Williams, M.; Oz, M.C.; Hicklin, D.J.; Witte, L.; Moore, M.A.S.; Rafii, S.: Blood 2000, 95 , 952.

14, Bhattacharya, V.; McSweeney, P.A.; Shi, Q.; Ishida, A.; Nash, R.; Storb, R.F.; Sauvage, L.R.; Hammond, W.P.: Blood 2000, 95 , 581.

15, Noishiki, Y.; Tomizawa, Y.; Yamane, Y.; Matsumoto, A.: Nat. Med. 1996, 2 , 90.

16, Kalka, C.; Masuda, H.; Takahashi, T.; Kalka-Moll, W.M.; Silver, M.; Kearney, M.; Li, T.; Isner, J.M.; Asahara, T.: Proc. Natl. Acad. Sci. USA 2000, 97, 3422.

17, Murohara, T.; Ikeda, H.; Duan, J.; Shintani, S.; Sasaki, K.; Eguchi, H.; Onitsuka, I.; Matsui, K.; Imaizumi, T.: J. Clin. Invest. 2000, 105 , 1527.

18, Masuda, H.; Asahara, T.: Cardiovasc. Res. 2003, 58, 390.

19, Kawamoto, A.; Tkebuchava, T.; Yamaguchi, J.I.; Nishimura, H.; Yoon, Y.-U.; Milliken, C.; Uchida, S.; Masuo, O.; Iwaguro, H.; Ma, H.; Hanley, A.; Silver, M.; Kearney, M.; Losordo, D.W.; Isner, J.M.; Asahara, T.: Circulation 2003, 107, 461.

20, Kupatt, C.; Horstkotte, J.; Vlastos, G.A.; Pfosser, A.; Lebherz, C.; Semisch, M.; Thalgott, M.; Buttner, K.; Browarzyk, C.; Mages, J.; Hoffman, R.; Deten, A.; Lamparter, M.; Muller, F.; Beck, H.; Buning, H.; Boekstegers, P.; Hatzopoulos, A.K.: FASEB J. 2005, 19 , 1576. 
21, Jia, L.; Takahashi, M.; Yoshioka, T.; Morimoto, H.; Ise, H.; Ikeda, U.: Curr Vasc Pharmacol 2006, 4, 59.

22, Sweeney, E.A.; Lortat-Jacor, H.; Priestley, G.V.; Nakamoto, B.; Papayannopoulou, T.: Blood 2002, 99, 44.

23, Mauray, S.; Sternberg, C.; Theveniaux, J.; Millet, J.; Sinquin, C.; Tapon-Bretaudiere, J.; Fischer, A.M.: Thromb. Haemost. 1995, $74,1280$.

24, Colliec, S.; Fischer, A.M.; Tapon-Bretaudiere, J.; Boisson-Vidal, C.; Durand, P.; Jozefonvicz, J.: Thromb. Res. 1991, 64, 143.

25, Charreau, B.; Blondin, C.; Boisson-Vidal, C.; Soulillou, J.P.; Anegon, I.: Transplantation Proceedings 1997, 29, 889.

26, Tissot, B.; Daniel, R.: Glycobiology 2003, 13, 29.

27, Witvrouw, M.; de Clercq, E.: Gen Pharmacol 1997, 29 , 497.

28, Matou, S.; Helley, D.; Chabut, D.; Bros, A.; Fischer, A.M.: Thromb. Res. 2002, 106 , 213.

29, Deux, J.F.; Meddahi-Pelle, A.; Le Blanche, A.F.; Feldman, L.J.; Colliec-Jouault, S.; Bree, F.; Boudghene, F.; Michel, J.B.; Letourneur, D.: Arterioscer Thromb Vasc Biol 2002, 22 , 1604.

30, Luyt, C.E.; Meddahi-Pelle, A.; Ho-Tin-Noe, B.; Colliec-Jouault, S.; Guezennec, J.; Louedec, L.; Prats, H.; Jacob, M.P.; Osborne-Pellegrin, M.; Letourneur, D.; Michel, J.B.: J. Pharmacol. Exp. Ther. 2003, 305 , 24.

31, Pereira, M.S.; Melo, F.R.; Mourao, P.A.S.: Glycobiology 2002, 12, 573.

32, Berteau, O.; Mulloy, B.: Glycobiology 2003, 13 , 29R.

33, Boisson-Vidal, C.; Haroun, F.; Ellouali, M.; Blondin, C.; Fischer, A.M.; de Agostini, A.; Jozefonvicz, J.: Drugs Fut. 1995, 20 , 1237.

34, Haroun, F.; Lindenmeyer, F.; Lu, H.; Soria, C.; Jozefonvicz, J.; Boisson-Vidal, C.: Anticancer Res. 2002, 22 , 214.

35, Thorlacius, H.; Vollmar, B.; Seyfert, U.T.; Vestweber, D.; Menger, M.D.: European Journal of Clinical Investigation 2000, 30, 804.

36, Sadir, R.; Baleux, F.; Grosdidier, A.; Imberty, A.; Lortat-Jacob, H.: J. Biol. Chem. 2001, 276 , 8288.

37, Mauray, S.; De Raucourt, E.; Talbot, J.C.; Dachary-Prigent, J.; Jozefowicz, M.; Fischer, A.M.: Biophys. Acta 1998, 1387, 184.

38, Chery, F.; Bittoun, P.; Colliec-Jouault, S.; Ratiskol, J.; Fermandjian, S.; Boisson-Vidal, C.: International Journal of Chromatography 2000, $6,7$.

39, Richard, B.; Bouton, M.C.; Loyau, S.; Lavigne, D.; Letourneur, D.; Jandrot-Perrus, M.; Arocas, V.: Thromb. Haemost. 2006, $95,229$.

40, Isner, J.M.; Asahara, T.: J. Clin. Invest. 1999, 103 , 1231.

41, Patan, S.: J. Neurooncol. 2002, 50, 1. 
42, Eichmann, A.; Pardanaud, L.; Yuan, L.; Moyon, D.: J. Hematother. Stem Cell Res. 2002, 11 , 207.

43, Flamme, I.; Risau, W.: Development 1992, 116, 435.

44, Hatzopoulos, A.K.; Folkman, J.; Vasile, E.; Eiselen, G.K.; Rosenberg, R.D.: Development $1998,125,1457$.

45, Takahashi, T.; Kalka, C.; Masuda, H.; Chen, D.; Silver, M.; Kearney, M.; MAgner, M.; Isner, J.M.; Asahara, T.: Nat. Med. 1999, 5 , 434.

46, Choi, K.; Kennedy, M.; Kazarov, A.; Papadimitriou, J.C.; Keller, G.: Development 1998, 125 , 725 .

47, Nishikawa, S.I.; Nishikawa, S.; Hirashima, M.; Matsuyoshi, N.; Kodama, H.: Development 1998, $125,1747$.

48, Millauer, B.; Wizigmann-Voos, S.; Schnurch, H.; Martinez, R.; Moller, N.P.; Risau, W.; Ullrich, A.: Cell 1993, $72,835$.

49, Sato, T.N.; Tozawa, Y.; Deutsch, U.; Wolburg-Buchholz, K.; Fujiwara, Y.; Gendron-Maguire, M.; Gridley, T.; Wolburg, H.; Risau, W.; Qin, Y.: Nature 1995, 376 , 70.

50, Yano, M.; Iwama, A.; Nishio, H.; Suda, J.; Takada, G.; Suda, T.: Blood 1997, 89, 4317.

51, Yamaguchi, T.P.; Dumont, D.J.; Conlon, R.A.; Breitman, M.L.; Rossant, J.: Development 1993, 118, 489.

52, Lapidot, T.; Petit, I.: Exp. Hematol. 2002, 30, 973.

53, Aicher, A.; Zeiher, A.M.; Dimmeler, S.: Hypertension 2005, 45 , 321.

54, Papayannopoulou, T.: Ann NY Acad Sci 1999, 872, 187.

55, Moore, M.A.; Hattori, K.; Heissig, B.; Shieh, J.H.; Dias, S.; Crystal, R.G.; Rafii, S.: Ann. N. Y. Acad. Sci. 2001, 938, 36.

56, Asahara, T.; Takahashi, T.; Masuda, H.; Kalka, C.; Chen, D.; Iwaguro, H.; Inai, Y.; Silver, M.; Isner, J.M.: EMBO J. 1999, $18,3964$.

57, Aiuti, A.; Webb, I.J.; Bleul, C.; Springer, T.; Gutierrez-Ramos, J.C.: J. Exp. Med. 1997, 185 , 111.

58, Lapidot, T.: Ann. N. Y. Acad. Sci. 2001, 938, 83.

59, Ceradini, D.J.; Kulkarni, A.R.; Callaghan, M.J.; Tepper, O.M.; Bastidas, N.; Kleinman, M.E.; Capla, J.M.; Galiano, R.D.; Levine, J.P.; Gurtner, G.C.: Nat. Med. 2004, 10, 858.

60, Hattori, K.; Heissig, B.; Tashiro, K.; Tateno, M.; Shieh, J.H.; Hackett, N.R.; Quitoriano, M.S.; Crystal, R.G.; Rafii, S.; Moore, M.A.: Blood 2001, 97, 3354.

61, Laterveer, L.; Lindley, I.J.; Hamilton, M.S.; Willemze, R.; Fibbe, W.E.: Blood 1995, 85, 2269.

62, Kocher AA, Schuster MD, Bonaros N, Lietz K, Xiang G, Martens TP, Kurlanski P, Sondermeijer H, Boyle A, Homma S, Wang SF, Itescu S. Myocardial homing and 
neovascularization by human bone marrow angioblasts is regulated by IL-8/Gro CXC chemokines. J Mol Cell Cardiol 2006, In Press.

63, Schomig K, Busch G, Steppich B, Sepp D, Kaufmann J, Stein A, Schomig A, Ott I. Interleukin-8 is associated with circulating CD133 + progenitor cells in acute myocardial infarction. Eur Heart J 2006, in Press.

64, Vasa, M.; Fichtlscherer, S.; Adler, K.; Aicher, A.; Martin, H.; Zeiher, A.M.; Dimmeler, S.: Circulation 2001, 103 , 2885.

65, Heeschen C, Aicher A, Lehmann R, Fichtlscherer S, Vasa M, Urbich C, Mildner-Rihm C, Martin H, Seiher AM, Dimmeler S. Erythropoietin is a potent physiological stimulus for endothelial progenitor cell mobilization. Blood 2003, 102, 1340.

66, Levy-Adam, F.; Abboud-Jarrous, G.; Guerrini, M.; Beccati, D.; Vlodavsky, I.; Ilan, N.: J. Biol. Chem. 2005, 280, 20457.

67, Amara, A.; Lorthioir, O.; Valenzuela, A.; Thelen, M.; Virelizier, J.L.; Delepierre, M.; Baleux, F.; Lortat-Jacob, H.; Arenzana-Seisdedos, F.: J. Biol. Chem. 1999, 274 , 2396.

68, Davis, G.E.; Senger, D.R.: Circ. Res. 2005, 97, 1093.

69, Bowder, T.; Folkman, J.; Pieie-Shepherd, S.: J. Biol. Chem. 2000, 275 , 1521.

70, Brooks, P.C.; Clark, R.A.F.; Cheresh, D.A.: Science 1994, 264 , 569.

71, Elicieri, B.P.; Cheresh, D.A.: J. Clin. Invest. 1999, 103, 1227.

72, Lapierre, F.; Holme, K.; Lam, L.; Tressler, R.J.; Storm, N.; Wee, J.; Stack, R.J.; Castellot, J.; Tyrrell, D.J.: Glycobiology 1996, 6, 355.

73, Rosengart, T.K.; Budenbender, K.T.; Duenas, M.; Mack, C.A.; Zhang, Q.X.; Isom, O.W.: $J$ Vasc Surg 1997, 26, 302.

74, Hasan, J.; Shnyder, S.D.; Clamp, A.R.; McGown, T.; Bicknell, R.; Presta, M.; Bibby, M.; Double, J.; Craig, S.; Leeming, D.; Stevenson, K.; Gallagher, J.T.; Jayson, G.C.: Clin. Cancer Res. 2005, 11, 8172.

75, Casu, B.; Guerrini, M.; Guglieri, S.; Naggi, A.; Perez, M.; Torri, G.; Cassinelli, G.; Ribatti, D.; Carminati, P.; Penco, S.; Pisano, C.; Belleri, M.; Rusnati, M.; Presta, M.: J Med Chem 2004, 47,838 .

76, Thornton, M.; Barkley, L.; Mason, J.C.; Shaunak, S.: Antimicrob. Agents Chemother. 1999, 43,2528 .

77, Zugmaier, G.; Lippman, M.E.; Wellstein, A.: J Natl Cancer Inst 1992, 84 , 1716.

78, Hahnenberger, R.; Jakobson, A.M.; Ansary, A.; Wehler, T.; Svahn, C.M.; Lindahl, U.: Glycobiology 1993, 3, 567.

79, Joyce, J.A.; Freeman, C.; Meyer-Morse, N.; Parish, C.R.; Hanahan, D.: Oncogene 2005, 24 , 4037.

80, Hoffman, R.: Biochem. J. 1993, $289,331$.

81, Matsubara, K.: Curr Med Chem - Cardiovasc and Hematol Agents 2004, 2 , 13. 
82, Zugmaier, G.; Favoni, R.; Jaeger, R.; Rosen, N.; Knabbe, C.: Ann NY Acad Sci 1999, 886, 243.

83, Klepacek, I.; Smetana, K.J.; Stol, M.: Folia Biol (Praha) 1993, 39 , 51.

84, Hahnenberger, R.; Jakobson, A.M.: Glycoconjugate J. 1991, 8, 350.

85, Li, W.W.; Casey, R.; Gonzalez, E.M.; Folkman, J.: Invest Ophtalomol Visual Sci 1991, 32 , 2898.

86, Benelli, U.; Bocci, G.; Danesi, R.; Lepri, A.; Bernadini, N.; Bianchi, F.; Lupetti, M.; Dolfi, A.; Campagni, A.; Agen, C.; Nardi, M.; Del Tacca, M.: Exp. Cell Res. 1998, 67, 133.

87, Folkman, J.; Langer, R.; Lindardt, R.J.; Haudenschild, C.; Taylor, S.: Science 1983, 221 , 719.

88, Hoffman, R.; Paper, D.H.; Donaldson, J.; Vogl, H.: Br. J. Cancer 1996, 73 , 1183.

89, Matsubara, K.; Xue, C.; Zhao, X.; Mori, H.; Sugawara, T.; Hirata, T.: Int J Mol Med 2005, 15 , 695 .

90, Chabut, D.; Fischer, A.M.; Colliec-Jouault, S.; Laurendeau, I.; Matou, S.; Le, B.B.; Helley, D.: Mol. Pharmacol. 2003, 64, 696.

91, Zemani, F.; Benisvy, D.; Galy-Fauroux, I.; Lokajczyk, A.; Colliec-Jouault, S.; Uzan, G.; Fischer, A.M.; Boisson-Vidal, C.: Biochem Pharmacol 2005, 70 , 1167.

92, Soeda, S.; Kozako, T.; Iwata, K.; Shimeno, H.: Biochim. Biophys. Acta 2000, 1497, 127.

93, Koyanagi, S.; Tanigawa, N.; Nakagawa, H.; Soeda, S.; Shimeno, H.: Biochem. Pharmacol. 2003, $65,173$.

94, Mulloy, B.; Ribeiro, A.-C.; Alves, A.-P.; Vieira, R.P.; Mourao, P.A.S.: J. Biol. Chem. 1994, $269,22113$.

95, Mourao, P.A.S.; Pereira, M.S.; Pavao, M.S.G.; Mulloy, B.; Tollefsen, D.M.; Mowinckel, M.C.; Abildgaard, U.: J. Biol. Chem. 1996, 271 , 23973.

96, Church, F.C.; Meade, J.B.; Treanor, R.E.; Whinna, H.C.: J. Biol. Chem. 1989, 264 , 3618.

97, Colliec-Jouault, S.; Fischer, A.M.; Tapon-Bretaudière, J.; Boisson, C.; Jozéfonvicz, J.: Thromb. Res. 1991, 64, 143.

98, Nishino, T.; Kiyohara, H.; Yamada, H.; Nagumo, T.: Phytochemistry 1991, 30 , 535.

99, Nishino, T.; Fukuda, A.; Nagumo, T.; Fujihara, M.; Kaji, E.: Thromb. Res. 1999, 96 , 37.

100, Pereira, M.S.; Mulloy, B.; Mourao, P.A.S.: J. Biol. Chem. 1999, 274, 7656.

101, Chaubet, F.; Chevolot, L.; Jozefonvicz, J.; Durand, P.; Boisson-Vidal, C. In Bioactive Carbohydrate Polymers; Paulsen, B.S., Ed.. 2000; pp. 59-83.

102, Millet, J.; Colliec-Jouault, S.; Mauray, S.; Theveniaux, J.; Sternberg, C.; Boisson-Vidal, C.; Fischer, A.M.: Thromb. Haemost. 1999, 81 , 391. 
103, Boisson-Vidal, C.; Chaubet, F.; Chevolot, L.; Sinquin, C.; Theveniaux, J.; Millet, J.; Sternberg, C.; Mulloy, B.; Fischer, A.M.: Drug Development Research 2000, 51 , 216.

104, Colliec-Jouault, S.; Millet, J.; Helley, D.; Sinquin, C.; Fischer, A.M.: J. Thromb. Haemost. $2003,1,1114$.

105, Giraux, J.L.; Tapon-Bretaudiere, J.; Matou, S.; Fischer, A.M.: Thromb. Haemost. 1998, 80 , 692.

106, Soeda, S.; Sakaguchi, S.; Shimeno, H.; Nagamatsu, A.: Biochem. Pharmacol. 1992, 43 , 1853.

107, Nishino, T.; Yamauchi, T.; Horie, M.; Nagumo, T.; Suzuki, H.: Thromb. Res. 2000, 99 , 623.

108, Chabut, D.; Fischer, A.M.; Helley, D.; Colliec, S.: Thromb. Res. 2004, 113 , 93.

109, Giraux, J.L.; Matou, S.; Bros, A.; Tapon-Bretaudiere, J.; Letourneur, D.; Fischer, A.M.: Eur. J. Cell Biol. 1998, 77, 352.

110, McCaffrey, T.A.; Falcone, D.J.; Borth, W.; Brayton, C.F.; Weksler, B.B.: Biochem. Biophys. Res. Commun. 1992, $184,773$.

111, Logeart, D.; Prigent-Richarc, S.; Boisson-Vidal, C.; Chaubet, F.; Durand, P.; Jozefonvicz, J.; Letourneur, D.: Eur. J. Cell Biol. 1997, 74 , 385.

112, Patel, M.K.; Mulloy, B.; Gallagher, K.L.; O'Brien, L.; Hughes, A.D.: Thromb. Haemost. $2002,87,149$.

113, Boisson-Vidal, C., Calliguiri, G. 2006. Personal Communication

114, Sweeney, E.A.; Priestley, G.V.; Nakamoto, B.; Collins, R.G.; Beaudet, A.L.; Papayannopoulou, T.: Proc. Natl. Acad. Sci. USA 2000, 97, 6544.

115, Frenette, P.S.; Weis, L.: Blood 2000, 96, 2460.

116, Gospodarowicz, D.; Cheng, J.: J. Cell. Physiol. 1986, 128, 475.

117, Belford, D.A.; Hendry, I.A.; Parish, C.R.: J. Cell. Physiol. 1993, 157, 184.

118, Coltrini, D.; Rusnati, M.; Zoppetti, G.; Oreste, P.; Isacchi, A.; Caccia, P.; Bergonzoni, L.; Prista, M.: Eur. J. Biochem. 1993, 214, 51.

119, Volkin, D.B.; Tsai, P.K.; Dabora, J.M.; Gress, J.O.; Burke, C.J.; Linhardt, R.J.; Middaugh, C.R.: Arch. Biochem. Biophys. 1993, $300,30$.

120, Mach, H.; Middaugh, C.R.: Arch. Biochem. Biophys. 1994, 309, 36.

121, Boisson-Vidal, C.; Colliec-Jouault, S.; Fischer, A.M.; Tapon-Bretaudière, J.; Stenberg, C.; Durand, P.; Jozéfonvicz, J. In Drugs of the Future.; Prous, J.P., Ed.. 1991; pp. 539-545.

122, Chevolot, L.; Mulloy, B.; Ratiskol, J.; Foucault, A.; Colliec-Jouault, S.: Carbohydr. Res. 2001, 330, 529.

123, Daniel, R.; Berteau, O.; Chevolot, L.; Varenne, A.; Gareil, P.; Goasdue, N.: Eur. J. Biochem. 2001, 268, 5617. 
124, Marais, M.F.; Joseleau, J.P.: Carbohydr. Res. 2001, 336, 155.

125, Mulloy, B.: An Acad Bras Cienc 2005, $77,651$.

126, Tapon-Bretaudiere, J.; Chabut, D.; Zierer, M.; Matou, S.; Helley, D.; Bros, A.; Mourao, P.A.S.; Fischer, A.M.: Mol Cancer Res 2002, 1 , 96.

127, Zancan, P.; Mourao, P.A.S.: Blood Coagul. Fibrinolysis 2004, 15 , 45.

128, Tissot, B.; Montdargent, B.; Chevolot, L.; Varenne, A.; Descroix, S.; Gareil, P.; Daniel, R.: Biochim. Biophys. Acta 2003, 1651, 5.

129, O'Leary, R.; Rerek, M.; Wood, E.J.: Biol. Pharm. Bull. 2004, 27, 266.

130, Rerek, M.; Wood, E.J.: Biol Pharm Bull 2004, 27 , 266.

131, McCaffrey, T.A.; Falcone, D.J.; Vicente, D.; Du, B.; Consigli, S.; Borth, W.: J. Cell. Physiol. $1994,159,51$.

132, Senni, K.; Gueniche, F.; Fouault-Bertaud, A.; Igondjo-Tchen, S.; Fioretti, F.; Colliec-Jouault, S.; Durand, P.; Guezennec, J.; Godeau, G.; Letourneur, D.: Arch Biochem Biophys 2006, 445 , 56.

133, Blondin, C.; Fischer, E.; Boisson-Vidal, C.; Kazatchkine, M.; Jozefonvicz, J.: Mol. Immunol. 1994, $31,247$.

134, Oehninger, S.; Clark, G.F.; Fulgham, D.; Blackmore, P.F.; Mahony, M.C.; Acosta, A.A.; Hogden, G.D.: J. Androl. 1992, 13 , 519.

135, Varki, A.: Proc. Natl. Acad. Sci. USA 1994, 91 , 7390.

136, Handa, K.; Nudelman, E.D.; Stroud, M.R.; Shiozawa, T.; Hakomori, S.: Biochem. Biophys. Res. Commun. 1991, 181, 1223.

137, Preobrazhenskaya, M.E.; Berman, A.E.; Mikhailov, V.I.; Ushakova, N.A.; Mazurov, A.V.; Semenov, A.V.; Usov, A.I.; Nifant'ev, N.E.; Bovin, N.V.: Biochem. Mol. Biol. Int. 1997, 43, 443.

138, Verfaillie, C.M. In Hematology, Basic Principles and Pratice; Hoffman, R.; Benz, E.J.; Shattil, S.J.; Furie, B.; Cohen, H.J.; Silberstein, L.E.; McGlave, P., Ed.. New York, 2000; pp. $143-154$

139, Hidalgo, A.; Peired, A.J.; Weiss, L.A.; Katayama, Y.; Frenette, P.S.: Blood 2004, 104 , 993.

140, Smyth, S.S.; Patterson, C.: J. Cell Biol. 2002, 158, 17.

141, Siler, U.; Seiffert, M.; Puch, S.; Richards, A.; Torok-Storb, B.; Muller, C.A.; Sorokin, L.; Klein, G.: Blood 2000, 96 , 4194.

142, Gu, Y.C.; Kortesmaa, J.; Tryggvason, K.; Personn, J.; Ekblom, P.; Jacobsen, S.E.; Ekblom, M.: Blood 2003, $101,877$.

143, Qian H, Tryggvason K, Jacobsen SE, Ekblom M. Contribution of \{alpha\}6-integrins to hematopoietic stem and progenitor cell homing to bone marrow and collaboration with \{alpha\}4-integrins. Blood 2006, in Press. 
144, Quarto, N.; Amalric, F.: J Cell Sci 1994, 107, 3201.

145, Forsten-Williams, K.; Chua, C.C.; Nugent, M.A.: J. Theor. Biol. 2005, 233 , 483.

146, Horowitz, A.; Tkachenko, E.; Simons, M.: J Cell Biol 2002, 157 , 715.

147, Sastry, S.K.; Lakonishok, M.; Wu, S.; Truong, T.Q.; Huttenlocher, A.; Turner, C.E.; Horwitz, A.F.: J. Cell Biol 1999, $144,1295$.

148, Shimaoka, M.; Ikeda, M.; Iida, T.; Taenaka, N.; Yoshiya, I.; Honda, T.: Am J Respir Crit Care Med 1996, 153 , 307.

149, Teixeira, M.M.; Hellewell, P.: Brit J Pharmacol 1997, 120, 1059.

150, Omata, M.; Matsui, N.; Inomata, N.; Ohno, T.: J Cardiovasc Pharmacol 1997, 30 , 717.

151, Cetin, C.; Kose, A.A.; Aral, E.; Colak, O.; Ercel, C.; Karabagli, Y.; Alatas, O.; Eker, A.: Ann Plast Surg 2001, 47, 540.

152, Netelenbos, T.; van den Born, J.; Kessler, F.L.; Zweegman, S.; Merle, P.A.; van Oostveen, J.W.; Zwaginga, J.J.; Huijgens, P.C.; Drager, A.M.: Leukemia 2003, 17 , 175.

153, Heng, B.C.; Liu, H.; Cao, T.: Med Hypotheses 2005, 65 , 414.

154, Peattie, R.A.; Rieke, E.R.; Hewett, E.M.; Fisher, R.J.; Shu, X.Z.; Prestwich, G.D.: Biomaterials 2006, $27,1868$.

155, Voermans, C.; Kooi, M.L.; Rodenhuis, S.; van der Lelie, H.; van der Schoot, C.E.; Gerritsen, W.R.: Blood 2001, 97, 799. 


\section{Captions :}

Figure 1: Fucoidan induces a proangiogenic phenotype in human EPC. 1A - Fucoidan enhances EPC proliferation in a concentrations-dependent manner starting at $1 \mu \mathrm{g} / \mathrm{ml}$. $1 \mathrm{~B}$ Fucoidan-pre-treatment does not have any effect on the DNA synthesis of cultured EPC and does not induce any cell-cycle arrest. 2 - Fucoidan pre-treatment enhances HUVEC but not EPC attachment to laminin. Untreated-EPC show 3-fold greater adhesion to laminin than HUVEC, baseline $\alpha 6$ subunit expression on EPC is already sufficient for maximal adhesion to laminin. 3 - Fucoidan pre-treatment promotes EPC motility and enhances EPC chemotaxis towards VEGF. 4 - Fucoidan pre-treatment enhances FGF-2-induced vascular tube formation by EPC. 4A : EPC do not form tubular structures in control medium. 4B : 18h after seeding, FGF-2-pretreated cells are elongated and interconnected. 4C-D : The tubular network is significantly more extensive in the presence of FGF-2 and LMW fucoidan.

Figure 2 : Fucoidan induces mobilization of immature $\mathrm{CD} 34^{+} / \mathrm{CD} 31^{+} / \mathrm{CD} 45^{-}$murine progenitors. Wild mice were intraperitoneal injected with PBS (negative control), $5 \mathrm{mg} / \mathrm{kg}$ of LMW fucoidan (LMWF) or $0.5 \mu \mathrm{g} / \mathrm{kg}$ VEGF (positive control) and bled $30 \mathrm{~min}$ after the injection. Blood was assayed for $\mathrm{CD} 34^{+} / \mathrm{CD} 31^{+} / \mathrm{CD} 45^{-}$cells and plasma samples were analyzed for SDF-1 concentration by enzymelinked immunosorbent assay test (Quantikine). A : Progenitors mobilization after intraperitoneal injection of PBS (negative control), LMW fucoidan (LMWF) or VEGF (positive control). B : SDF-1 level in mice plasma after intraperitoneal injection of fucoidan compared to controls. Results are expressed as the means \pm S.E.M. $* \mathrm{p}<0.05, * * * \mathrm{p}<0.001$.

$\underline{\text { Figure } 3}$ :Repeating disaccharide structures of sulphated polysaccharides. A : Fucoidan extracted from brown seaweed Ascophyllum nodosum or Fucus vesiculosum [122]. B : Heparin/heparan sulphate. C : Pentosan sulphate. D and E : Chondroitin 4 and 6 sulphates. F : Fucosylated chondroitin sulphate from sea cucumber [95].

$\underline{\text { Figure } 4}$ : Model for fucoidan effect in cell growth and angiogenesis. Fucoidan binds FGF-2 present in the matrix or in the supernatant. A - Fucoidan protects FGF-2 from proteolytic degradation. B Fucoidan can interact with cell membrane by non-covalent linkage to different cell-surface 
macromolecules such as integrin or selectins, allowing delivery of active FGF-2. Signals resulting from "receptor" activation support growth and angiogenesis. C - The observed $\alpha 6$ overexpression on the endothelial cell surface is partly mediated by FGF-2 and HSPGs. Fucoidan-bound receptor can transduce, like HSPGs, outside-in signals leading to overexpression of $\alpha 6$ subunit integrin.

$\underline{\text { Figure } 5}$ : Hypothesized proangiogenic effect of fucoidan in vivo. A - Fucoidan can bind to, potentiate and inactivate cationic proteins such as adherent proteins expressed in MEC and bone marrow, enzymes, growth factors, cytokines... B - Fucoidan can prevent thrombosis, catalysing thrombin inhibition, promoting fibrinolysis and stimulating the release of tissue factor pathway inhibitor (TFPI). C - Fucoidan can promote EPC mobilization by displacing sequestered SDF-1 from HSPG. It can also compete with EPC for binding HSPG or ECM proteins. D - Fucoidan can bind to EPC and induce a proangiogenic phenotype to EPC, by enhancing their motility. E - Fucoidan enhances EPC chemotaxis toward VEGF, EPC attachment to laminin and growth factor-induced vascular tube formation, improving revascularization of ischemic tissue. 
Figure 1: Fucoidan induces a proangiogenic phenotype in human EPC. 1A - Fucoidan enhances EPC proliferation in a concentrations-dependent manner starting at $1 \mu \mathrm{g} / \mathrm{ml}$. $1 \mathrm{~B}$ Fucoidan-pre-treatment does not have any effect on the DNA synthesis of cultured EPC and does not induce any cell-cycle arrest. 2 - Fucoidan pre-treatment enhances HUVEC but not EPC attachment to laminin. Untreated-EPC show 3-fold greater adhesion to laminin than HUVEC, baseline $\alpha 6$ subunit expression on EPC is already sufficient for maximal adhesion to laminin. 3 - Fucoidan pre-treatment promotes EPC motility and enhances EPC chemotaxis towards VEGF. 4 - Fucoidan pre-treatment enhances FGF-2-induced vascular tube formation by EPC. 4A : EPC do not form tubular structures in control medium. 4B : 18h after seeding, FGF-2-pretreated cells are elongated and interconnected. 4C-D: The tubular network is significantly more extensive in the presence of FGF-2 and LMW fucoidan.

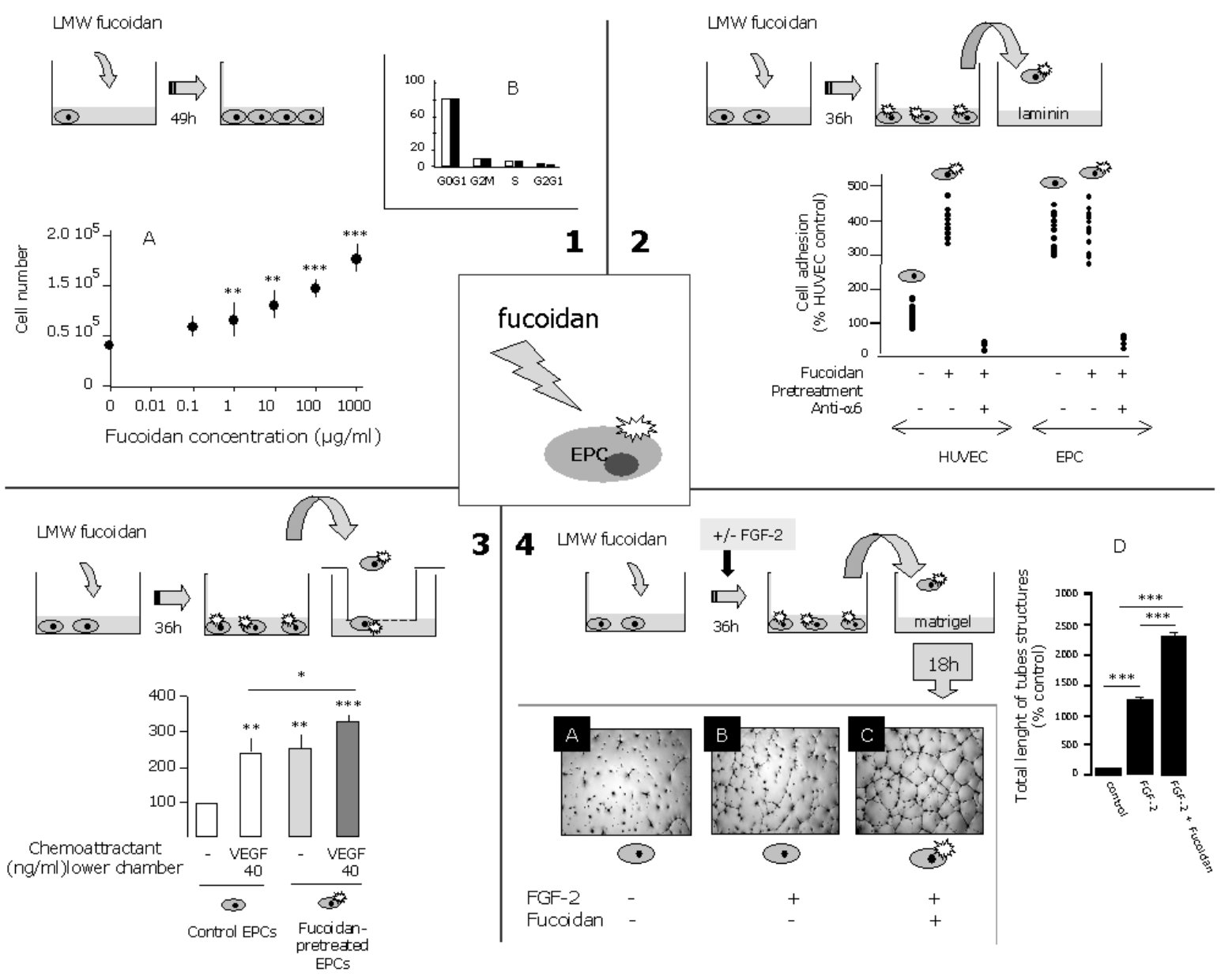


Figure 2 : Fucoidan induces mobilization of immature $\mathrm{CD} 34^{+} / \mathrm{CD} 31^{+} / \mathrm{CD} 45^{-}$murine progenitors. Wild mice were intraperitoneal injected with PBS (negative control), $5 \mathrm{mg} / \mathrm{kg}$ of LMW fucoidan (LMWF) or $0.5 \mu \mathrm{g} / \mathrm{kg}$ VEGF (positive control) and bled $30 \mathrm{~min}$ after the injection. Blood was assayed for $\mathrm{CD} 34^{+} / \mathrm{CD} 31^{+} / \mathrm{CD} 45^{-}$cells and plasma samples were analyzed for SDF-1 concentration by enzymelinked immunosorbent assay test (Quantikine). A : Progenitors mobilization after intraperitoneal injection of PBS (negative control), LMW fucoidan (LMWF) or VEGF (positive control). B : SDF-1 level in mice plasma after intraperitoneal injection of fucoidan compared to controls. Results are expressed as the means \pm S.E.M. $* \mathrm{p}<0.05, * * * \mathrm{p}<0.001$.
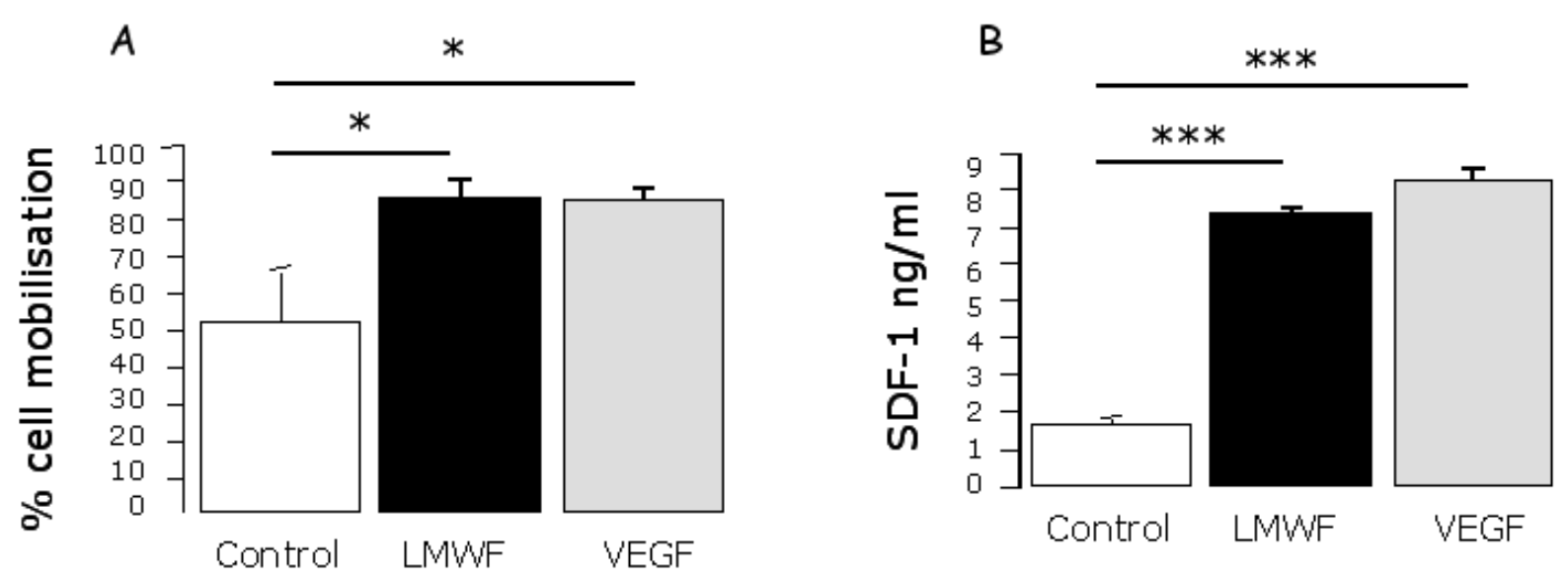
Figure 3 :Repeating disaccharide structures of sulphated polysaccharides. A : Fucoidan extracted from brown seaweed Ascophyllum nodosum or Fucus vesiculosum [122]. B : Heparin/heparan sulphate. C : Pentosan sulphate. D and E : Chondroitin 4 and 6 sulphates. F : Fucosylated chondroitin sulphate from sea cucumber [95].

\section{A - Fucoidan}

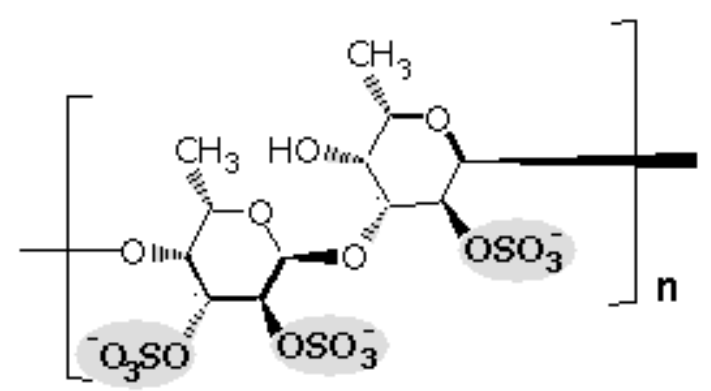

C - Pentosan polysulfate

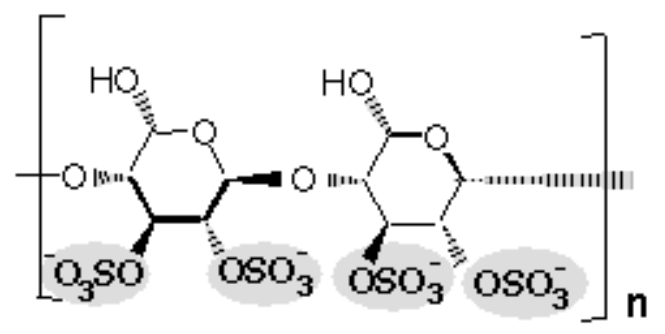

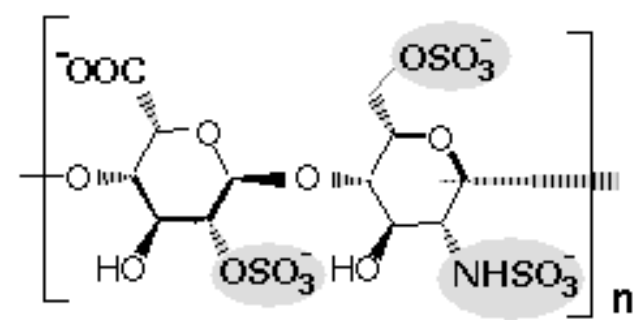

D - Chondroitin 4 sulphate

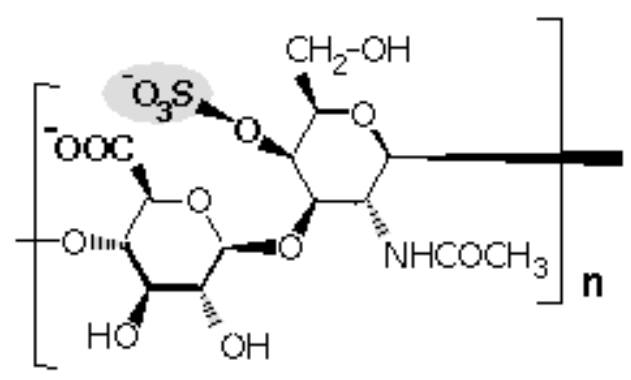

F - Fucosylated chondroitin sulphate

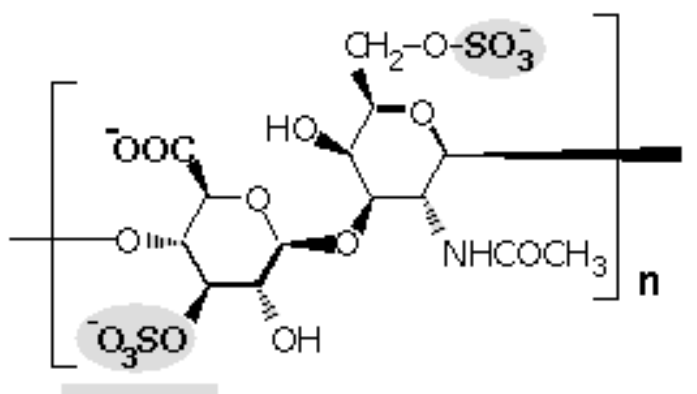

or

fucose 
Figure 4 : Model for fucoidan effect in cell growth and angiogenesis. Fucoidan binds FGF-2 present in the matrix or in the supernatant. A - Fucoidan protects FGF-2 from proteolytic degradation. B Fucoidan can interact with cell membrane by non-covalent linkage to different cell-surface macromolecules such as integrin or selectins, allowing delivery of active FGF-2. Signals resulting from "receptor" activation support growth and angiogenesis. C - The observed $\alpha 6$ overexpression on the endothelial cell surface is partly mediated by FGF-2 and HSPGs. Fucoidan-bound receptor can transduce, like HSPGs, outside-in signals leading to overexpression of $\alpha 6$ subunit integrin.

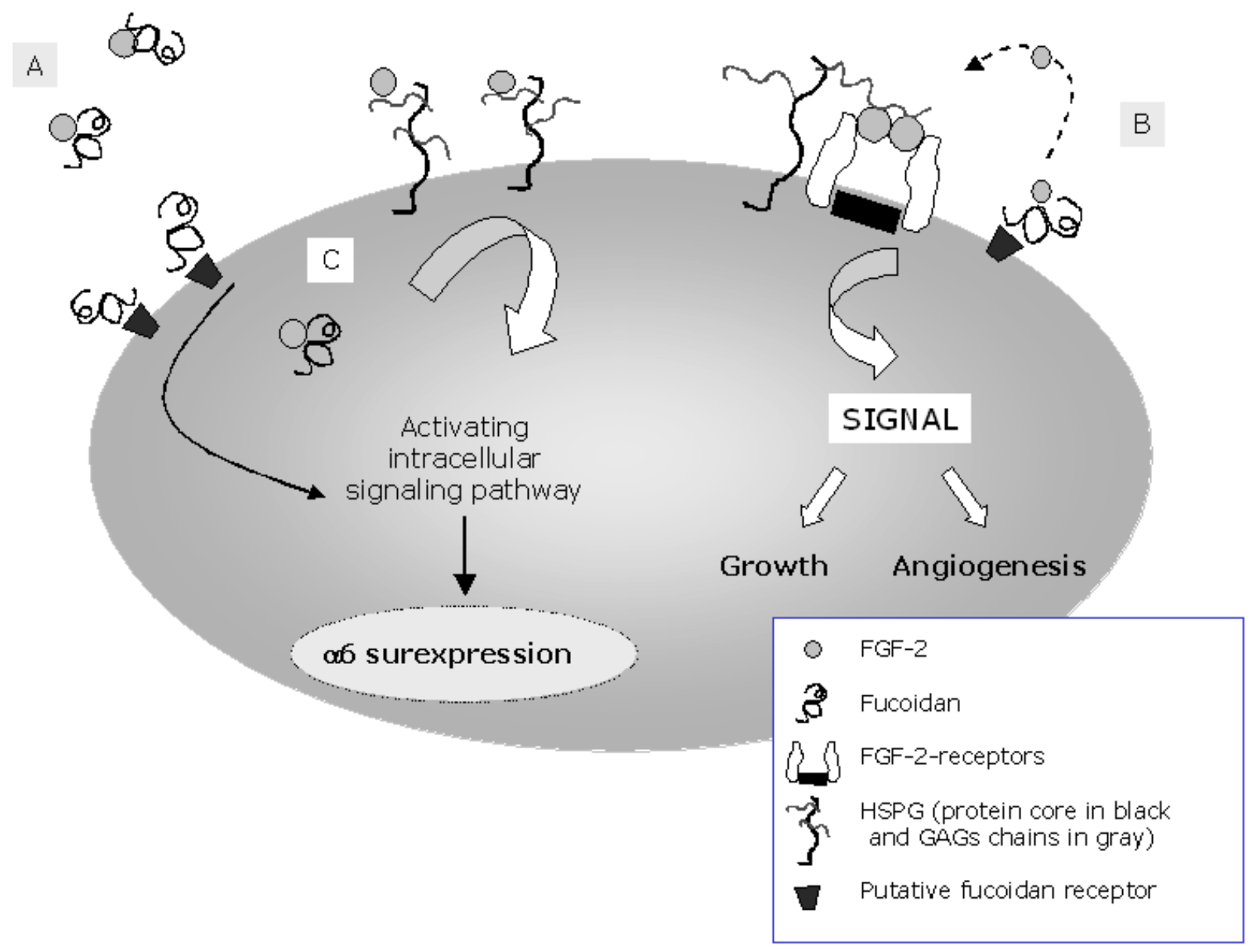


Figure 5 : Hypothesized proangiogenic effect of fucoidan in vivo. A - Fucoidan can bind to, potentiate and inactivate cationic proteins such as adherent proteins expressed in MEC and bone marrow, enzymes, growth factors, cytokines... B - Fucoidan can prevent thrombosis, by catalysing thrombin inhibition, by promoting fibrinolysis and stimulating the release of tissue factor pathway inhibitor (TFPI). C - Fucoidan can promote EPC mobilization by displacing sequestered SDF-1 from HSPG. It can also compete with EPC for binding HSPG or ECM proteins. D - Fucoidan can bind to EPC and induce a proangiogenic phenotype to EPC, by enhancing their motility. E - Fucoidan enhances EPC chemotaxis toward VEGF, EPC attachment to laminin and growth factor-induced vascular tube formation, improving revascularization of ischemic tissue.

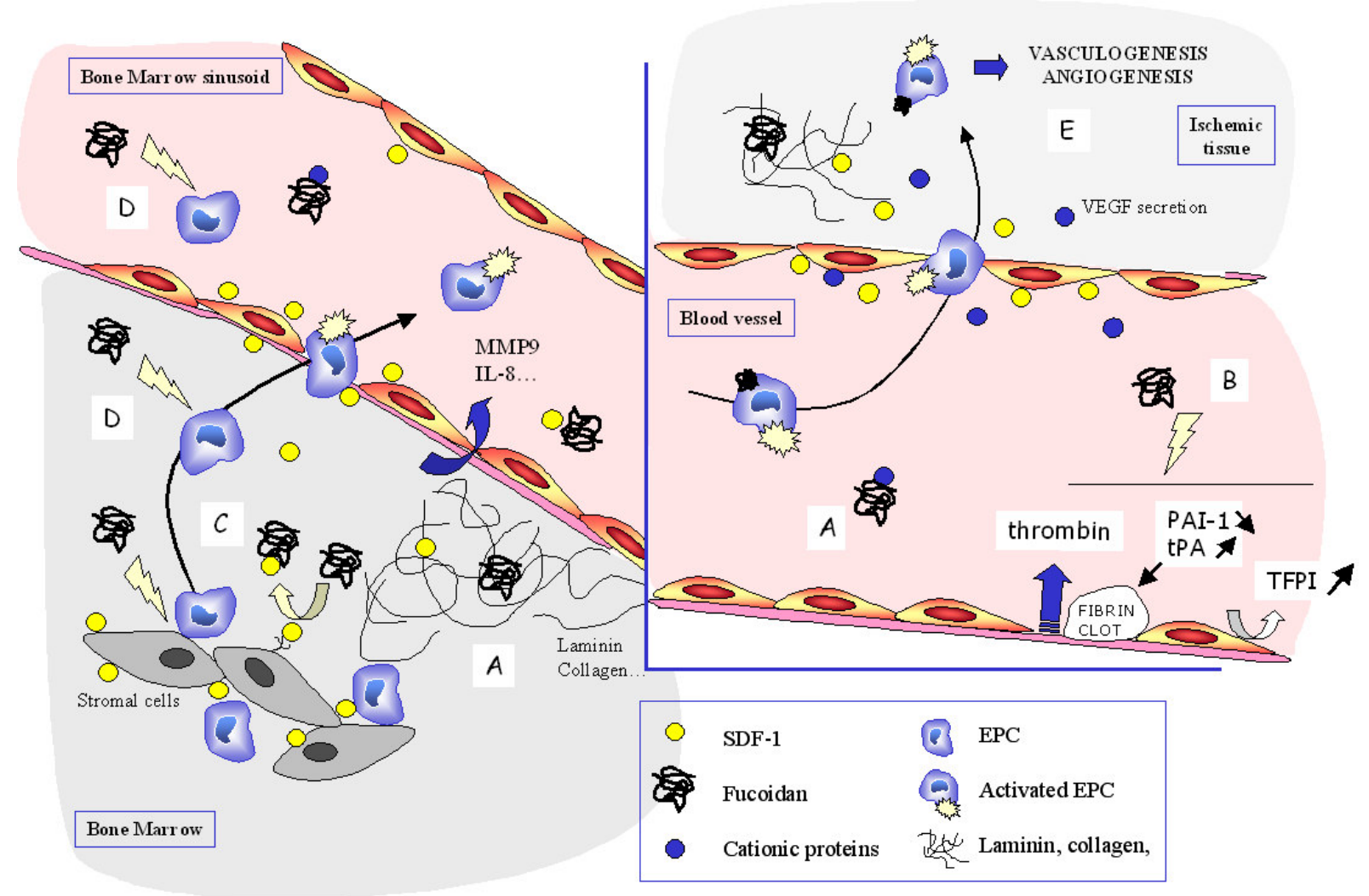

